\title{
Notification Letter To Begin Investigation (SPDP) As Supervision and Control Function of Criminal Acts of Corruption Case Investigation
}

\author{
Farida Kaplele \\ Faculty of Law, Cenderawasih University \\ Jl. Kamp. Wolker, Waena, Jayapura, 99358, Papua, Indonesia \\ Tlp:08114805415_E-mail: farida.kaplele@yahoo.com \\ DOI: 10.31957/plj.v3i1.632
}

\begin{abstract}
The procedural design of criminal case handling under the Criminal Procedure Code (KUHAP) places a Notification Letter to Begin an Investigation (SPDP) as an initial step in monitoring and controlling investigation. The KUHAP Control and Supervision Model by placing SPDP is lex specialis as the initial instrument of control and supervision of corruption case investigation, but this has undergone changes that can reduce the principle of functional coordination of investigation and at the same time negate the authority of the Public Prosecutor to follow up on investigation of corruption case due to the Decision of the Constitutional Court (MK) Number 130/PUU-XIII/2015. Thus, the Public Prosecutor is no longer in the position of supervisor and controller of investigation of corruption case, because the public prosecutor is only authorized as the apparatus of the investigation results, receives the minutes of investigation (BAP) and receives legal means of proof and suspects to proceed to the trial phase. The implementation of SPDP after the Constitutional Court Decision No. 130/PUU-XIII/2015 brings a new atmosphere in the criminal justice process specifically at the pre-trial phase that requires adjustments, and the rest cannot be accurately predicted, therefore it is recommended that the investigator of Indonesian National Police (Polri) can renew the Standard Operating Procedure in order to be more adaptive and professional.
\end{abstract}

Keywords: Investigation; Criminal Acts of Corruption.

\section{INTRODUCTION}

As with the disclosure of criminal cases in general, before going to the prosecution and examination phase at the trial, the disclosure of corruption cases also goes through a series of processes for finding suspects and collecting evidence. According to the provisions of criminal procedural law, this is commonly referred to as a preliminary investigation and investigation. In Article 1 number (5) of the Criminal Procedure Code, what is meant by preliminary investigation is "a series of acts by junior 
investigator to seek and find an event that is presumed to be an offense in order to determine whether or not an investigation can be carded out by means regulated in the law". While Article 1 number (3) states that investigation shall be "a series of acts by an investigator in matters and by means regulated in the law to seek and gather evidence with which to clarify whether an offense has occurred and to locate the suspect. ${ }^{1}$

${ }^{1}$ If it is only based on the provisions contained in Article 1 paragraph (3) and paragraph (4) of the Criminal Procedure Code, then those who can act as preliminary investigator and investigator are National Police of the Republic of Indonesia. However, the explanation of Article 284 of the Criminal Procedure Code states that there are exceptions to the implementation of the provisions in the Criminal Procedure Code, namely the implementation of Law No. 7 Drt. of 1955 concerning Investigation, Prosecution and Economic Criminal Justice and the Law on the Eradication of Criminal Acts of Corruption (see explanation of Article 284 of Law No. 8 of 1981), then in special criminal acts of corruption, besides the police, the prosecutor shall have the right to act as a preliminary investigator and investigator. In further development, law enforcement against corruption is not only handled by the police and prosecutor. At this time, the Corruption Eradication Commission $(K P K)$ formed by Law No. 30 of 2002 has the duty of conducting preliminary investigation and investigation of corruption, as referred to in Article 6 letter c of Law No. 30 of 2002. However, there are limitations on the authority of the Corruption Eradication Commission in terms of preliminary investigation and investigation as contained in Article 11. In addition to these three institutions, there is currently a joint team whose membership comes from the prosecutor's office, the police and the
The initial step of the investigator in conducting an investigation is to inform the Public Prosecutor. This is in accordance with the provision in Article 109 paragraph (1) of the Criminal Procedure Code, that: "In case an investigator has already started the investigation of an event which constitutes a criminal act, he shall inform the public prosecutor about the matter". The provision in Article 109 paragraph (1) of the Criminal Procedure Code contain meaning that with the receipt of a notification letter from the investigator to the Public Prosecutor, this means the starting point of the Public Prosecutor involvement in a case whose material is mentioned in the notification letter. The logical consequence of the notification is the commencement of an investigation by an investigator of an event presumed to be an offense, the notification letter shall contain: (1) the suspect (with a complete identity), (2) offence alleged to have been committed by

Financial and Development Supervisory Agency are also authorized to conduct preliminary investigation and investigation of corruption cases. This team is formed based on Presidential Decree No. 11 of 2005 concerning the Corruption Eradication Coordination Team (Tastipikor). 
the suspect (although it is incomplete), (3) collected evidence; and (4) whether the suspect is arrested or not. If there are other criminal acts committed by the suspect, it shall be mentioned in the BAP.

The provisions of Article 109 of the Criminal Procedure Code as mentioned above apply to handling special crimes such as corruption as long as they are not regulated separately in Law No. 31 of 1999 in conjunction with Law No. 20 of 2001 concerning Eradication of Criminal Acts of Corruption.

As is well-known, the provisions of Law No. 31 of 1999 in conjunction with Law No. 20 of 2001 concerning the Eradication of Criminal Acts of Corruption (UUTPK) states that investigation, prosecution and examination in court trial against criminal acts of corruption are conducted based on applicable criminal procedure law, unless otherwise stipulated in this law and must take precedence over other matters for immediate resolution. ${ }^{2}$ Investigation based on Article 1 Paragraph (2) of the Criminal Procedure

2 Andi Hamzah, (1983). Pengantar Hukum Acara Pidana Indonesia, Jakarta: PT Ghalia Indonesia. p. 122
Code, Law No. 8 of 1981 is a series of acts by an investigator in matters and by means regulated in the law to seek and gather evidence with which to clarify whether an offense has occurred and to locate the suspect.

The provisions of Law on Criminal Acts of Corruption regarding investigation, prosecution and examination in court trial against corruption as explained above, have consequences that can be applied in lex generalis of the provisions concerning investigations in the Criminal Procedure Code, and are related to the procedures for investigation, duties, obligations and authorities of an investigator, including supervision and control integrated in the functional coordination of criminal justice apparatus. One of the provisions of criminal case investigation (in casu case of corruption) is the provision of investigation relating to the presence of SPDP. Article 109 of the Criminal Procedure Code states that:

(1) Where an investigator has begun the investigation of an event that constitutes an offense, the investigator shall inform the public prosecutor of this fact.

(2) Where an investigator terminates an investigation because of the absence of sufficient evidence or it has become clear that said event 
did not constitute an offense or the investigation has been terminated by virtue of law, the investigator shall inform the public prosecutor, the suspect or his family of this fact.

(3) Where the termination referred to in Paragraph (2) is effected by an investigator as intended by Article 6 Paragraph (1) letter b, notification of this fact shall promptly be delivered to the investigator and the public prosecutor.

The provisions in Article 109 of the Criminal Procedure Code above mean coordination and check and balance relations between investigator and public prosecutor relating to an investigation of corruption cases in 3 (three) important matters of SPDP, namely (1) SPDP shall be submitted to the Public Prosecutor if investigator begins to investigate corruption cases, (2) In case the investigation is terminated, SPDP shall be submitted to both Public Prosecutor and the suspect or his family, and (3) the provisions in paragraph (2) apply to Civil Servant Investigator (PPNS).

In its development, the provisions of Article 109 of the Criminal Procedure Code have changed after the Constitutional Court
Decision Number 130/PUUXIII/2015 has interpreted several provisions in the Criminal Procedure Code considered contrary to the constitution such as Article 14 letter b, Article 138 paragraph (2), and Article 109 of the Criminal Procedure Code. Therefore, the author is interested to examine the implementation of SPDP in the corruption case and its relevance to the authority of investigator in investigating corruption cases and the supervision and control functions of investigation by Public Prosecutor, so that the objectives of investigation can be achieved in particular and it is related to the principles of best practice and conviction rate in handling corruption cases in general.

\section{METHOD}

The method used in this study was descriptive normative method. Thus, an analysis of the substance of legal norms relating to the investigation of corruption case was carried out and evaluated to obtain recommendations in resolving existing problems. The procedure for identifying and inventorying legal materials includes primary legal 
material in the form of legislation, secondary legal materials, consisting of literature and legal scientific works and tertiary legal material of legal dictionary. The legal materials were inventoried, identified and analyzed qualitatively.

\section{DISCUSSION}

In the implementation of investigator's duties to disclose a criminal act including corruption, the investigator due to his duties has the authority as stated in the provisions of Article 1 paragraph (1) of the Criminal Procedure Code, that investigator's authorities are (1) to accept report or complaint from a person about the existence of an offense; (2) to take the first step at the place of occurrence; (3) to order a suspect to stop and examine the suspect's identification; (4) to carry out arrest, detention, search and seizure; (5) to fingerprint and photograph a person; (6) to summon a person to be heard or examined as a suspect or a witness; (7) to call in an expert required in connection with the examination of a case; (8) to terminate an investigation; (9) to take other responsible acts in accordance with law. Thus, investigation is carried out by the police or certain civil servants granted special authority by law to conduct investigation. In case of crimes which are difficult to prove, a joint team may be formed.

In the practice of criminal justice against criminal acts of corruption, dualism of authority often occurs in the investigation function of the police and prosecutor who functionally have the authority to prosecute. Moreover, the investigation of criminal acts of corruption is categorized as a special criminal act, so that the investigation is specifically different from the general investigation of criminal acts.

To avoid overlapping of investigation authority ${ }^{3}$, a joint decision was made, namely the Joint Regulation of the Chair of the Supreme Court of the Republic of Indonesia, the Minister of Law and Human Rights of the Republic of Indonesia, the Attorney General of the Republic of Indonesia, and the

\footnotetext{
3 See Hibnu Nugroho, (2009) "Rekonstruksi Wewenang Penyidik Dalam Perkara Tipikor (Kajian Wewenang Polisi Dalam Penyidikan Tipikor)", Journal of Legal Media. Vol. 16 No. 3 December, Yogyakarta: FH UMY, p. 3
} 
National Police Chief No. 151/KMA/SKB/IX/2011, No. M.HH08.HM.03.02 of 2011, No. KEP215/A/JA/09/2011, No. B/24/IX/2011 concerning Coordination among Law Enforcement Officers in the Prevention and Eradication of Criminal Acts of Corruption. The initial motivation of this Joint Regulation was to maintain harmonization of authority among law enforcement officers. ${ }^{4}$

In Article 5 paragraph (2) of the Joint Regulation, it is stated that in the event that the Police and Prosecutor conduct an investigation of Criminal Acts of Corruption on the same case, to avoid duplication in the investigation, then the agency that has the obligation to follow up the investigation is the agency that first issued the Notification Letter to Begin Investigation. Furthermore,

\footnotetext{
4 See Soerjono Soekanto, (1983). Faktor-faktor Yang Mempengaruhi Penegakan Hukum. Jakarta: Rajawali Press. p.5. states that law enforcers are those who are directly involved in the field of law enforcement, including law enforcement and peace maintenance. Law enforcers shall carry out their duties properly in accordance with their respective roles that have been regulated in legislation. In carrying out these duties, they shall prioritize justice and professionalism, so that it becomes a role model for the community and is trusted by all parties including all members of the community.
}

Paragraph (3) states the results of an investigation by an agency that does not continue its investigation must be submitted to the agency that follows up the investigation, in order to speed up the process of further investigation. If an offense is known to an investigator, then he shall immediately take action in accordance with his authority, then make the report and/or minutes of measures for further settlement. After an event that has occurred is suspected to be a known criminal offense, an investigation, reporting activities, examination, and settlement and submission of case files are immediately carried out.

In Article 5 paragraph (2) of the Joint Regulation, it is stated that in the event that the Police and Prosecutor conduct an investigation into Corruption Crime on the same case, to avoid duplication in the investigation, then the agency that has the obligation to follow up the investigation is the agency that first issued the Notification Letter to Begin Investigation. Furthermore, Paragraph (3) states the results of an investigation by an agency that does not continue its investigation must be 
submitted to the agency that follows up the investigation, in order to speed up the process of further investigation. if an offense is known to an investigator, then he shall immediately take action in accordance with his authority, then make the report and/or minutes of measures for further settlement. After an event that has occurred is suspected to be a known criminal offense, an investigation, reporting activities, examination, and settlement and submission of case files are immediately carried out.

When the investigation began, the investigator had obtained two legal means of proof. ${ }^{5}$ According to Article 184 Paragraph (1) of the Criminal Procedure Code, legal means of proof shall be the testimony of a witness, the testimony of an expert, document, an indication, the testimony of the accused. When the investigator began the investigation, he has come to the conviction that an offense has truly occurred and has sufficient data and facts to conduct an investigation of the offense. The commencement of the investigation is

${ }^{5}$ Harun M Husein, (1985). Penangan Perkara dalam Proses Peradilan Pidana. Jakarta: PT Bina Aksaran. p. 14 preceded by a notification to the attorney general that an investigation into a criminal event has begun. Formally, the notification is conveyed through a mechanism of the Notification Letter to Begin Investigation which is at least accompanied by an incident report and letter of investigation order. This is regulated in the provisions of Article 109 of the Criminal Procedure Code. In connection with the definition of the commencement of investigation, PAF. Lamintang states: "An investigator shall be seen as having begun an investigation, which is immediately after he has used the authority of his investigation as stated by the law (Article 7 of the Criminal Procedure Code) to him, because his actions directly involve people's rights suspected of committing an offense, either regarding their freedom, good name or wealth". The definition of the commencement of investigation as stated above reveals that if an act or forced effort has been carried out by the investigator such as calling, investigation, detention, search, confiscation, etc. contained in the letter for justice. 
The implementation of SPDP is regulated in Article 109 of the Criminal Procedure Code, the problem is that there is no firmness of the provisions about when the investigation shall be notified by the public prosecutor. Based on the background above, the author was interested in conducting the study entitled Juridical Review of the Implementation of Notification Letter to Begin Investigation on Criminal Acts of Corruption.

However, the implementation of the KUHAP's functional coordination model as described above has changed after the Decision of Constitutional Court Number 130/PUU-XIII/2015, stating that: “Article 109 paragraph (1) of Law No. 8 of 1981 concerning Criminal Procedure, State Gazette of 1981 No. 76, Additional State Gazette No. 3209 contradict the 1945 Constitution of the Republic of Indonesia conditionally and do not have binding legal force as long as the phrase "investigator shall notify the public prosecutor" is not interpreted that the investigator shall notify and submit the Notification Letter to Begin Investigation to the Public Prosecutor, the Accussed, and Victim within a maximum of 7 (seven) days after the issuance of the letter of investigation order.

The existence of the Decision of Constitutional Court No. 130/PUUXIII/2015 has not only changed the functional coordination model established by the Criminal Procedure Code, but also changed the model of supervision and control of the Public Prosecutors as referred to in Article 109 paragraph (1) of the Criminal Procedure Code. Consequently, the Public Prosecutor can no longer carry out the function of supervision and control of investigation of corruption cases because the investigator no longer has the obligation (in this case the police investigator) to submit the SPDP to the suspect. On the contrary, The Public Prosecutor no longer has any repressive authority to supervise and control investigation except during the pre-prosecution process. However, in the process of preprosecution of corruption cases, other Articles can be petitioned and stated in their considerations not to contradict the Constitution, such as Article 138, Article 139, Article 14 
letter b of Criminal Procedure Code. Thus, the Articles remain valid.

\section{CONCLUSION}

The Criminal Procedure Code control and supervision model by placing SPDP as the initial instrument of control and supervision of investigation of corruption cases has undergone changes that can reduce the principle of functional coordination of the investigation and at the same time negate the authority of the Public Prosecutor to follow from the start of investigations into corruption cases. Thus, the Public Prosecutor is no longer in the position of supervisor and controler of investigation, because the public prosecutor is only authorized as the apparatus of the outcome of the investigation by accepting BAP and the rest receiving evidence and suspects to be continued at the trial phase. The Decision of Constitutional Court No. 130/PUU-XIII/2015 brings new atmosphere in the criminal justice process specifically at the pre-trial phase which requires adjustment, and the rest cannot be accurately predicted related to its impact, therefore it is recommended to the National Police Investigator to renew the Standard Operating Procedure to be more adaptive and professional.

\section{BIBLIOGRAPHY}

Hamzah, Andi. (1983). Pengantar Hukum Acara Pidana Indonesia. Jakarta: PT Ghalia Indonesia

Nugroho, Hibnu. (2009). Rekonstruksi Wewenang Penyidik Dalam Perkara Tipikor (Kajian Wewenang Polisi dalam Penyidikan Tipikor. Journal of Legal Media. VoL. 16. No. 3. Desember 2009. Yogyakarta: FH UMY.

Husein, Harun M.. (1985). Penangan Perkara dalam Proses Peradilan Pidana. Jakarta: PT Bina Aksaran Jakarta.

Mas, Marwan. (2014). Pemberantasan Tindak Pidana Korupsi. Bogor: Ghalia Indonesia.

Soekanto, Soerjono. (1983). Faktorfaktor Yang Mempengaruhi Penegakan Hukum. Jakarta. Rajawali Press. 